\title{
Forecasting Unemployment Rate in the Aftermath of the Covid-19 Pandemic: The Turkish Case
}

\author{
Mustafa Batuhan TUFANER ${ }^{1}$, İlyas SÖZEN 2
}

\begin{abstract}
The coronavirus (Covid-19) pandemic caused the loss of lives, global problems, and the collapse of economies. Especially, the high unemployment rates in developing countries at present makes the unemployment rate predictions important. The aim of this study is to estimate the unemployment rate for the future by ARIMA and Artificial Neural Networks (ANN) models for Turkey. The contribution of the study to the literature is to estimate the unemployment rate in Turkey in the aftermath of the Covid-19 by ARIMA and ANN models. In the study, the Box-Jenkins method was used to find the appropriate ARIMA process. Then, the estimated performance of the results obtained up to $2021 \mathrm{M} 8$ unemployment rates in Turkey have been compared in the framework of criteria for success. Our results show that ANN was more successful than the ARIMA model in estimating the unemployment variable. It seemed that the unemployment rate estimated by the model is very close to the actual unemployment rate. According to the model results, in the aftermath of Covid-19, the unemployment rate in Turkey will be occurred over $5 \%$ of the natural rate of unemployment.
\end{abstract}

Keywords: Covid-19, Unemployment, Artificial Neural Networks, ARIMA, Turkey

JEL classification: E24, C53, C45

\section{Covid-19 Salgını Sonrası İssizlik Oranının Tahmini: Türkiye Örneği}

\begin{abstract}
Özet
Koronavirüs (Covid-19) salgını can kaybına, küresel sorunlara ve ekonomilerin çökmesine neden olmuştur. Özellikle gelişsmekte olan ülkelerdeki yüksek işsizlik oranları, isssizlik oranı tahminlerini önemli hale getirmektedir. Çalışmanın amacı, Türkiye için ARIMA ve Yapay Sinir Ağları (YSA) modelleri ile geleceğe yönelik ișsizlik oranını tahmin etmektir. Çalıșmanın literatüre katkısı, Covid-19 sonrasında Türkiye'deki işsizlik oranını ARIMA ve YSA modelleri ile tahmin etmektir. Çalışmada, uygun ARIMA sürecini bulmak için Box-Jenkins yöntemi kullanılmıştır. Ardından, Türkiye'de 2021M8 dönemine kadar işsizlik oranlarından elde edilen sonuçların tahmini performansı kriterlere göre karşılaştırılmıştır. Bulgular, YSA'nın işsizlik değişsenini tahmin etmede ARIMA modelinden daha başarılı olduğunu göstermektedir. Model tarafindan tahmin edilen işsizlik oranının gerçek işsizlik oranına oldukça yakın olduğu görülmüştür. Model sonuçlarına göre Covid-19 sonrasında Türkiye'deki işsizlik oranı doğal işsizlik oranı olan \% 5'in üzerinde gerçekleșecektir.
\end{abstract}

Anahtar kelimeler: Covid-19, İssizlik, Yapay Sinir Ağları, ARIMA, Türkiye

JEL sınıflandırması: E24, C53, C45

\section{INTRODUCTION}

The coronavirus (Covid-19) pandemic, which emerged in Wuhan, China in December 2019, caused the loss of lives, global problems, and the collapse of economies due to the global interconnectedness of many people. Policymakers in countries are under pressure to find a balance in controlling the disease by imposing restrictions, and saving individuals' jobs and livelihoods by sustaining economic activity. Restrictions on the movement of both individuals and goods disrupted supply chains and accelerated the problem of unemployment. In this context, it has become

ATIF ÖNERİí (APA): Tufaner, M.B., Sözen, İ., (2021). Forecasting Unemployment Rate in the Aftermath of the Covid-19 Pandemic: The Turkish Case. İzmir İktisat Dergisi, 36(3), 685-693. Doi: 10.24988/ije.202136312

1 Dr. Öğr. Üyesi, Beykent Üniversitesi, İktisadi ve İdari Bilimler Fakültesi, İstanbul, EMAIL: batuhantufaner@beykent.edu.tr ORCID: 0000-0003-0415-4368

2 Prof. Dr., Dokuz Eylül Üniversitesi, Uygulamalı Bilimler Yüksekokulu, İzmir, EMAIL: ilyas.sozen@deu.edu.tr ORCID: 0000-0002-6503- 4696 


\section{B. TUFANER - İ. SÖZEN}

important for countries to evaluate the economic consequences of Covid-19.

Covid-19 can affect developing countries economically more. Especially, the high unemployment rates in developing countries at present makes the unemployment rate predictions important. In this context, estimating the unemployment rate in the aftermath of the Covid-19 in Turkey that has a high potential workforce and takes place in the ranking of developing countries, can create a prediction in terms of other developing countries. The aim of this study is to estimate the unemployment rate for the future by ARIMA and Artificial Neural Networks (ANN) models for Turkey. The contribution of the study to the literature is to estimate the unemployment rate in Turkey in the aftermath of the Covid-19 by ARIMA and ANN models. In the study, the Box-Jenkins method was used to find the appropriate ARIMA process. Then, the estimated performance of the results obtained up to 2021M6 unemployment rates in Turkey have been compared in the framework of criteria for success.

It is seen that autoregressive integrated moving average (ARIMA) models have been applied in previous studies on the estimation of the unemployment rate (Funke, 1992; Vicente et al., 2015). The utility and effectiveness of the classical linear ARIMA model is clear from the results obtained from using unemployment rate estimation datasets (Edlund and Karlsson, 1993; Dumičić et al., 2015) and non-sample estimates for the unemployment rate (Khan-Jafur et al., 2017). However, it was found that nonlinear models outperform linear models in the short-term forecast of seasonally adjusted monthly unemployment data (Proietti, 2003; Nagao et al., 2019).

It has become widespread to use non-classical methods to identify, and predict problems with complex systems. Artificial intelligence applications that can be used in many different areas have become more popular in recent years. Artificial neural networks are one of the most popular artificial intelligence methods today. The first study that applies the artificial neural network model to the economy belongs to White (1998). In the study, IBM's daily stock returns are estimated. Artificial neural networks have been used largely in three classes that are involved in economic applications. These are the classification of economic agents, time series estimation, and modeling of rational agents. Some studies highlighted the potential role of artificial neural networks in the context of predicting economic data (Herbrich et al., 1999; Chen et al., 2001; Nakamura, 2005; Choudhary and Haider, 2012). Previous results show that nonlinear models are very successful in capturing the asymmetry of unemployment rate time series for long-term forecast horizons (Feuerriegel and Gordon, 2019). In addition, the obvious disadvantage of neural networks is finding the "optimum" network architecture. To overcome this disadvantage, the autoregressive neural network (ARNN) model, which has recently been introduced in the literature, has been proposed (Faraway and Chatfeld, 1998). ARNN is a "white boxlike" model that connects a feed-forward neural network with a hidden layer to any time series data set with delayed values of the series as input (Teräsvirta et al., 2005).

Unemployment and inflation have been estimated in the USA using genetic support vector regression (Sermpinis et al., 2014). Unemployment and other macroeconomic variables have been estimated in $19 \mathrm{EU}$ countries using multilayer artificial neural networks (Coredo and Cabrera-Sanchez, 2020). GARCH and ARNN models were used to estimate unemployment in the UK (Johnes, 1999). Spatial Vector Autoregressions and Spatial Artificial Neural Network models were used to predict unemployment in his study on 35 Polish regions and found that the Spatial Vector Autoregressions model was 30\% more successful (Wozniak, 2018). FARIMA, GARCH, SVR, MARS and ANN models used to estimate unemployment in Med, Baltic, Balkan, Nordic, Benelux countries and found that the FARIMA 
model gives the best results (Katris, 2020). Four different neural network architectures were used Fully Connected, Convolutional, Recurrant, and Encoder-Decoder, to predict unemployment in the USA, and found that the Encoder-Decoder architecture gave better results (Cook and Hall, 2017).

ARDL and ANN models were used in the Phillips curve estimation for Iran (Jalaee et al., 2019). The validity of Okun's Law was estimated for 21 OECD countries using the SURE regression model (Bod'a and Považanová, 2021). Some studies worked on the forecast the unemployment rate in Turkey using by ARIMA and ANN models (Kizilkaya, 2017), by unobservable components model (Sengul and Tasci, 2020), and by the DFM models (Soybilgen and Yazgan, 2018). The ARIMA and feed forward artificial neural network (FFWD) model were used to predict youth unemployment in Italy (Fenga and Turan, 2020). In another study, ARIMA and autoregressive neural network method were used to predict unemployment in 7 developed countries and found that artificial neural networks give more successful results in the short term (Chakraborty et al., 2020).

\section{DATA AND METHODOLOGY}

The monthly unemployment rate for Turkey in the period 2014M1-2020M11 study data was used. Data obtained from TURKSTAT (https://www.tuik.gov.tr/). ARIMA and ANN models were used for the forecasting of unemployment rate. ANN can provide linear and nonlinear modeling without any prior knowledge between input and output variables. Therefore, ANN is general and flexible as a means of estimation compared to other methods (Zhang et al., 1998). ANN is widely used in financial and economic forecasting as a powerful modeling technique. Functions such as detecting functional relationships underlying the data set and pattern recognition, classification, evaluation, modeling, prediction, and control can be performed with ANN (Huang et al., 2007). It has successful applications in creating short- term estimates for time series, especially thanks to its pattern defining features in data. In time series forecasting with ANN, the inputs are formed in the past observations of the data series, while the output is the future predictive value. The period value desired to be predicted is represented in the output neuron, and the past observation values are represented in the input neuron (Hamzacebi, 2011).

If time is expressed as $t$, the output value is $y_{t}$ and the input values (yt-1, yt-2, yt-3, ...) consisting of past observation values; time series estimates can be obtained by estimating the $y_{t}=f\left(y_{t-1}, y_{t-2}, y_{t-3}, \ldots\right)$ function. Box-Jenkins is a method frequently used in univariate time series analysis. This method is used to make estimates by choosing the most suitable model among AR (p) (autoregressive), MA (q) (moving average), ARMA (p, q) (autoregressive moving average) and ARIMA (p, d, q) (integrated autoregressive moving average) models.

\subsection{Artificial Neural Networks}

ANN is an information processing system that basically works on the basis of connected processing elements working together to solve a problem, trying to imitate the human brain to find the pattern between input and output, and has common features with biological neural networks. The neural network is formed by the combination of many simple processing elements called neurons. Each neuron is connected with other neurons via weighted connections (Fausett, 1994). ANN has been proven to be an effective tool in nonparametric data in non-linear function forms such as job forecasting, credit scoring, bond evaluation, job failure prediction, medicine, pattern recognition, and image processing (Liliana and Napitupulu, 2012). The most important advantages of ANN over traditional statistical techniques are that it has fewer assumptions, and can model nonlinear relationships depending on the selection of activation functions. They can learn the events, and make rational decisions in the face of similar events. After ANN is trained, even if the 


\section{B. TUFANER - İ. SÖZEN}

data contains incomplete information, they can produce output. The information is stored throughout the network, and the loss of some of the artificial nerve cells does not cause the information to be lost. However, there are some disadvantages of ANN besides its advantages. There are too many parameters that can be changed depending on the user in ANN and there is no certain rule in determining the appropriate network structure. The type of activation function, the number of hidden layers, and the determination of the number of neurons in these layers are determined by trial and error. There is also no specific rule about when the training of the network should be completed. Also, the behavior of the network cannot be explained. This situation reduces trust in the network (Falat and Pancikova, 2015).

The Multi-Layer Perceptron (MLP), the most widely known and widely used ANN type, are general-purpose, non-linear models consisting of flexible and multi-layer neurons and have the ability to predict many functions. It is a widely used method because many learning algorithms can be used in MLP training. The MLP is a feed forward neural network consisting of the input layer, one or more hidden layers and output layers. Each neuron in one layer is connected to all neurons of the next layer, and there is forward communication from the input layer to the output layer (Popescu et al., 2009). During training, they work according to the teacher learning strategy, as both inputs, and output values corresponding to inputs are shown to the network. The most widely used learning algorithm for MLP is Feed-Forward (FFWD) architecture. In this algorithm, which works as an autoregressive (AR) type of signal processing, the outputs of the input layer, the inputs, and the linear combination of weights associated with the inputs themselves are the inputs in the hidden layer. The outputs are varied according to the nonlinear activation function and sent to the output layer that has only one neuron representing the predicted value. Figure 1 below shows an MLP structure with two hidden layers.

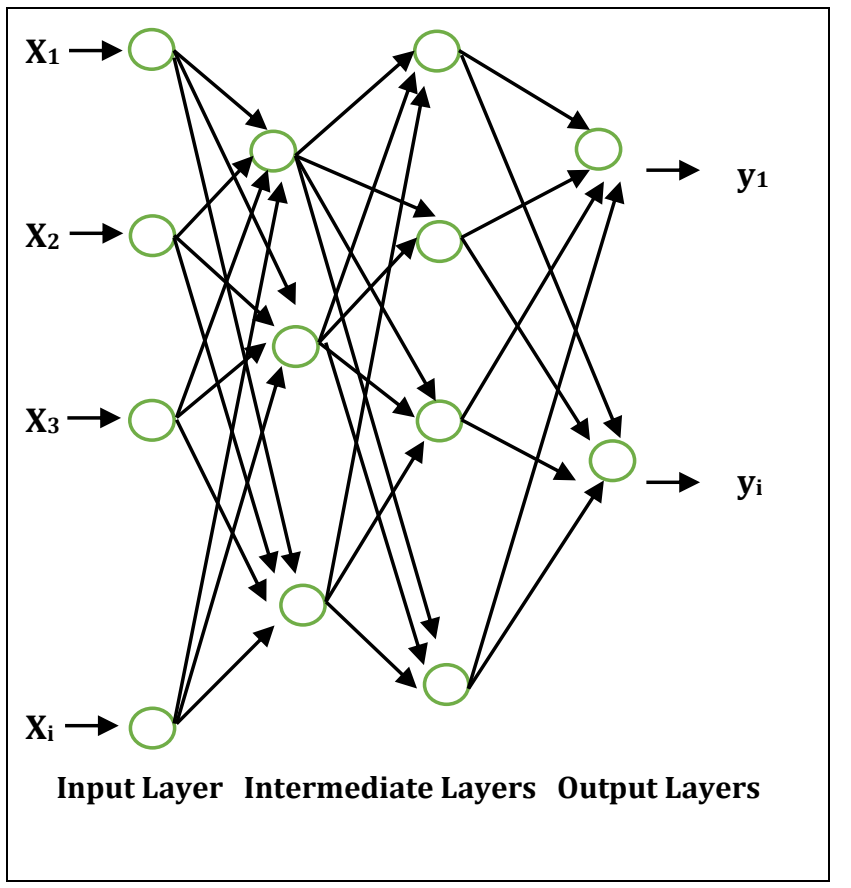

Figure 1: MLP with two hidden layers

The mathematical formulation of the artificial neural network is as follows:

$f\left(w^{0}, w^{1}, x\right)=\sum_{h} w_{h}^{1}(1+$

$\left.\exp \left(-\sum_{j} w_{j h}^{0} x_{i j}\right)\right)^{-1}=$

$\sum_{h} w_{h}^{1} \Phi\left(\sum_{j} w_{j h}^{0} x_{i j}\right)$

$\gamma_{i}=\sum_{h} w_{h}^{1} \phi\left(\sum_{j} w_{j h}^{0} x_{i j}\right)+\gamma_{i}$

While in some of the studies in the literature the value of the output neuron is a linear combination of the values of occult neurons (Chuku et al., 2017), some studies use a sigmoid activation function of the linear combination (Tkacz, 2001). Using a sigmoid function to connect the hidden layer to the output neuron means that the output in the network will always be in the (0-1) range.

\subsection{Box-Jenkins Method}

The Box-Jenkins method is based on the stinginess principle, which is expressed as using the least possible parameters for a model that adequately reflects the properties of the data (Akgul, 2003). The autoregressive process of the p. rank AR (p) is shown by Equation (3), the moving average of the q. rank MA (q) is shown by Equation (4) and the autoregressive 
moving average process of ARMA (p, q) is shown in Equation (5).

$$
\begin{aligned}
Y_{t} & =\delta+\alpha_{1} Y_{t-1}+\alpha_{2} Y_{t-2}+\cdots+\alpha_{p} Y_{t-p}+\varepsilon_{t} \\
Y_{t} & =\mu+\varepsilon_{t}+\beta_{1} \varepsilon_{t-1}+\beta_{2} \varepsilon_{t-2}+\cdots+\beta_{q} \varepsilon_{t-q} \\
Y_{t} & =\delta+\alpha_{1} Y_{t-1}+\alpha_{p} Y_{t-p}+\varepsilon_{t}+\beta_{1} \varepsilon_{t-1}+\cdots+\beta_{q} \varepsilon_{t-q}
\end{aligned}
$$

(5)

Along with these processes applied to stationary time series, ARIMA ( $p, d, q$ ) process is used for non-stationary series that become stationary by taking the difference from $\mathrm{d}$. degrees. Box-Jenkins is also a method to find the appropriate ARIMA ( $p, d, q)$ process. BoxJenkins method consists of four steps (Gujarati, 2004);

- Identification: Appropriate $\mathrm{p}, \mathrm{d}$, and $\mathrm{q}$ values are determined at this stage with the help of autocorrelation and partial autocorrelation function.

- Estimation: After determining the appropriate $p$ and $q$ values, the coefficients of the autoregressive and moving average terms included in the model are estimated.

- Diagnostic Checking: After a certain model is selected and the coefficients are estimated, it is checked whether the residues found from the selected model are white noise. If the remains are not white and noisy, it is necessary to go back to the beginning.

- $\quad$ Forecasting: One of the reasons why the Box-Jenkins method is widely used is its success in forecasting. It is more reliable than the traditional methods, especially in shortterm forecasting.

\section{FINDINGS}

Figures are used for the period 2014M12020M11 accessed from TURKSTAT website (https://www.tuik.gov.tr/) monthly unemployment rate in order to estimate the unemployment rate in Turkey. Existing data are arranged and given in Table 1.

The stationarity test of the series should be performed in order to determine whether the time series is stationary and its behaviors (trend and seasonality). ADF unit root test was used to determine whether the series contain unit root or not. The obtained test values are presented in Table 2.

Table 1: Unemployment rates between 20142020 (\%)

\begin{tabular}{|l|c|c|c|c|c|c|c|}
\hline \multirow{2}{*}{ Months } & \multicolumn{7}{|c|}{ Years } \\
\cline { 2 - 8 } & 2014 & 2015 & 2016 & 2017 & 2018 & 2019 & 2020 \\
\hline January & 10.5 & 11.6 & 11.3 & 13.3 & 11.1 & 15 & 14.1 \\
\hline February & 10.3 & 11.4 & 11.1 & 12.9 & 10.9 & 15 & 13.9 \\
\hline March & 9.9 & 10.8 & 10.3 & 12 & 10.3 & 14.3 & 13.5 \\
\hline April & 9.1 & 9.8 & 9.5 & 10.7 & 9.8 & 13.3 & 13.1 \\
\hline May & 8.9 & 9.5 & 9.6 & 10.4 & 9.9 & 13.1 & 13.2 \\
\hline June & 9.3 & 9.7 & 10.4 & 10.4 & 10.4 & 13.3 & 13.7 \\
\hline July & 10 & 10 & 11 & 10.9 & 11 & 14.2 & 13.7 \\
\hline August & 10.3 & 10.3 & 11.5 & 10.8 & 11.4 & 14.3 & 13.5 \\
\hline September & 10.7 & 10.5 & 11.6 & 10.8 & 11.7 & 14.1 & 12.9 \\
\hline October & 10.6 & 10.7 & 12 & 10.5 & 11.9 & 13.7 & 13 \\
\hline November & 10.9 & 10.7 & 12.3 & 10.5 & 12.6 & 13.6 & 13.1 \\
\hline December & 11.2 & 11 & 12.9 & 10.6 & 13.7 & 14 & \\
\hline
\end{tabular}

Table 2: ADF Unit root test results

\begin{tabular}{|c|c|c|c|c|}
\hline Variable & ADF Test & \multicolumn{3}{|c|}{ Critical Value } \\
\cline { 3 - 5 } & Statistics & $(\% 1)$ & $(\% 5)$ & $(\% 10)$ \\
\hline UNEM & -1.347 & -2.374 & -1.664 & -1.292 \\
\hline$\Delta$ UNEM & $-4.606^{*}$ & -2.375 & -1.665 & -1.292 \\
\hline
\end{tabular}

Note: * represents stationary at $5 \%$ significance level.

According to the results of ADF test statistics, it was determined that the UNEM series used in the analysis contained unit root at the level value and became stationary when the first difference of the series was taken. In the next step, the degrees of AR and MA are determined by looking at the autocorrelation function (ACF) and partial autocorrelation function (PACF) graphs of the series for the selection of models using the Box-Jenkins method. As a result of the tests, it was concluded that the coefficient of the autoregressive (AR) terms is 3 , the first-order difference (I) of the series is 1 , and the coefficient of the moving average (MA) terms is 2 . The results of the model are given in Table 3 below.

Table 3: Prediction parameters of the ARIMA $(3,1,2)$ model

\begin{tabular}{|c|c|c|c|c|}
\hline Variable & Coefficient & Std. Dev. & Statistics & Prob. \\
\hline AR (1) & 1.353838 & 0.1253899 & 10.80 & 0.000 \\
\hline AR (2) & -1.346059 & 0.1426419 & -9.44 & 0.000 \\
\hline AR (3) & 0.4004916 & 0.1195895 & 3.35 & 0.001 \\
\hline MA (1) & -0.6274732 & 0.1018626 & -6.16 & 0.000 \\
\hline MA (2) & 0.891263 & 0.0981568 & 9.08 & 0.000 \\
\hline
\end{tabular}

Note: Q statistics was used to test whether there is autocorrelation between residuals of the model and it was seen that there was no autocorrelation problem. 


\section{B. TUFANER - İ. SÖZEN}

While predicting with Artificial Neural Networks, the dataset is divided into parts such as training test or training-verificationtest. In this study, the first 65 values of the unemployment series (2014M1-2019M5) were used for training, and the last 17 values (2020M6-2021M10) for the test. In the ANN models, the sigmoid was used as the activation function. Since the sigmoid activation function can only produce values in the $(0,1)$ range, the input sets should also be normalized in the $(0,1)$ range. After the learning process was completed, the normalized data was converted to its original form by reverse processing.

In the study, it was aimed to determine which architectures predicted with less error by using different ANN structures for the estimation of unemployment variable, to compare it with the Box-Jenkins method, and to make predictions for the future with the best models obtained. The estimation values found as a result of the test process were compared with the actual values, and the estimation performances of the models were compared by considering the Mean Square Error (MSE). The established models were predicted with a feedforward (FFWD) architecture associated with an autoregressive (AR) signal processing algorithm. The estimation performances of the lowest error value of the created network structures are given in Table 4.

Table 4: MSE values for ANN and ARIMA models

\begin{tabular}{|c|c|c|c|}
\hline Model & $\begin{array}{c}\text { Number of } \\
\text { Neurons in } \\
\text { the Input } \\
\text { Layer }\end{array}$ & $\begin{array}{c}\text { Number of } \\
\text { Neurons in } \\
\text { Hidden Layers }\end{array}$ & MSE \\
\hline ARIMA & - & - & 0.0813615 \\
\hline ANN & 1 & 2 & 0.008188707 \\
\hline & 1 & 3 & 0.01574056 \\
\hline & 2 & 2 & 0.03989223 \\
\hline & 2 & 3 & 0.0183654 \\
\hline
\end{tabular}

Table 4 shows the MSE values showing the error levels of the series. As can be seen, the model with the lowest MSE value is the model with 1 input neurons. The MSE value of the relevant model was found to be 0.008188707 and this value was seen to have the lowest error level among the models used. As a result, the network structure giving the lowest MSE value was found as 1-2-1. In other words, the network structure where the number of neurons in the input layer is 1 and the number of neurons in the hidden layer is 2 is selected. Monthly unemployment rates forecasting using ARIMA $(3,1,2)$ and Artificial Neural Network models for the current time series are given in Table 5 below.

Table 5: Forecasting values obtained by ARIMA $(3,1,2)$ and ANN models

\begin{tabular}{|c|c|c|}
\hline Period & $\begin{array}{c}\text { Forecasting } \\
\text { (ARIMA) }\end{array}$ & Forecasting (ANN) \\
\hline November 2020 & 12.92 & 13.26 \\
\hline December 2020 & 13.47 & 13.67 \\
\hline January 2021 & 13.74 & 13.60 \\
\hline February 2021 & 13.50 & 13.46 \\
\hline March 2021 & 13.06 & 13.11 \\
\hline April 2021 & 12.93 & 13.35 \\
\hline May 2021 & 13.26 & 13.68 \\
\hline June 2021 & 13.75 & 14.03 \\
\hline July 2021 & 13.92 & 13.88 \\
\hline August 2021 & 13.67 & 13.63 \\
\hline
\end{tabular}

The actual unemployment rate announced on the TURKSTAT website for November 2020 is $13.10 \%$, and the proposed ANN model forecasting is $13.26 \%$. It is seen that the realized figures are very close to the forecasting values. According to these results, it can be stated that the proposed ANN model is a good predictor.

\section{CONCLUSION}

The aim of this study is to forecast the future rate of unemployment in Turkey with the best model using different ANN structures. The ANN models used in the study have the advantage of learning according to ARIMA models obtained by the Box-Jenkins method and successfully modeling nonlinear relationships without any prior knowledge and assumptions. In addition, there are disadvantages such as the lack of a specific rule in determining the structure of the network be established with ANN and the selection of parameters, the number of changeable parameters, and the inability to explain the behavior of the network.

When the estimation performances of the methods were examined, it was concluded that 
ANN was more successful than the ARIMA model in estimating the unemployment variable. Forecasting unemployment in the aftermath of the COVID-19 pandemic in Turkey has been produced with the help of ANN. While the unemployment rate announced for November 2020 was $13.10 \%$, the forecasting result of the model was found to be $13.26 \%$. It can be stated that the unemployment rate estimated by the model is very close to the actual unemployment rate.

The contribution of the study to the literature is to estimate the unemployment rate in
Turkey in the aftermath of the Covid-19 by ARIMA and ANN models. On the other hand, it is among the limited number of studies that produce future estimates with ANN and ARIMA models on the unemployment rate. According to the model results, in the aftermath of Covid-19, the unemployment rate in Turkey will be occurred over $5 \%$ of the natural rate of unemployment. In this context, in determining the optimum economic policies in the aftermath of the Covid-19, it would be appropriate for policymakers to steer macroeconomic policies by considering the forecasts in different studies.

\section{REFERENCES}

Akgul, I. (2003). Zaman serilerinin analizi ve arima modelleri. İstanbul: Der Yayınevi.

Bod'a, M. and Považanová, M. (2021). Outputunemployment asymmetry in Okun coefficients for OECD countries. Economic Analysis and Policy, 69, 307-323.

Chakraborty, T., Chakraborty, A., Biswas, M., Banerjee, S. and Bhattacharya, S. (2020). Unemployment rate forecasting: a hybrid approach. Computational Economics, 1-19.

Chen, X., Racine, J. and Swanson, N. (2001). Semiparametric arx neural network models with an application to forecasting inflation. IEEE Transactions on Neural Networks, 12, 674-683.

Choudhary, M. A. and Haider, A. (2012). Neural network models for inflation forecasting: an appraisal. Applied Economics, 44, 2631-2635.

Chuku C., Odour J. and Simpasa A. (2017). Intelligent forecasting of economic growth for African economies: artificial neural networks versus time series and structural econometric models. Forecasting Issues in Developing Economies 2017 conference paper. Washington.

Coredo, E. and Cabrera-Sanchez, J. P. (2020). Private label and macroeconomic indexes: an artificial neural networks application. Applied Science, 10(17), 1-13.
Dumičić, K., Čeh Časni, A. and Žmuk, B. (2015). Forecasting unemployment rate in selected European countries using smoothing methods. World Academy of Science, Engineering and Technology: International Journal of Social, Education, Economics and Management Engineering, 9, 867-872.

Edlund, P. O. and Karlsson, S. (1993). Forecasting the Swedish unemployment rate VAR vs. transfer function modelling. International Journal of Forecasting, 9, 61-76.

Falat, L. and Pancikova, L. (2015). Quantitative modelling in economics with advanced artificial neural networks. Procedia Economics and Finance, 34, 194-201.

Faraway, J. and Chatfield, C. (1998). Time series forecasting with neural networks: a comparative study using the airline data. Journal of the Royal Statistical Society: Series C (Applied Statistics), 47, 231-250.

Fausett, L. (1994). Fundamentals of neural networks: architecture, algorithms and applications, New Jersey: Prentice Hall.

Fenga, L. and Turan, S. S. (2020). Forecasting youth unemployment in the aftermath of the covid-19 pandemic: the Italian case. Research Square, DOI: 10.21203/rs.3.rs-74374/v1.

Feuerriegel, S. and Gordon, J. (2019). Newsbased forecasts of macroeconomic indicators: 


\section{B. TUFANER - İ. SÖZEN}

a semantic path model for interpretable predictions. European Journal of Operational Research, 272, 162-175.

Funke, M. (1992). Time-series forecasting of the German unemployment rate. Journal of Forecasting, 11, 111-125.

Gujarati, D. N. (2004). Basic econometrics, Fourth Edition, The McGraw-Hill Inc.

Hamzacebi, C. (2011). Yapay sinir ağları: tahmin amaçlı kullanımı Matlab ve Neurosolutions uygulamalı, Bursa: Ekin Yayıncilı.

Herbrich, R., Graepel, T. and Obermayer, K. (1999). Regression models for ordinal data: a machine learning approach, Technical report, TU Berlin. TR-99/03.

Huang, W., Lai, K. K., Nakamori, Y., Wang, S. and $\mathrm{Yu}, \mathrm{L}$. (2007). Neural networks in finance and economics forecasting. International Journal of Information Technology and Decision Making, 6, 113-140.

Jalaee, S. A., Lashkary, M. and GhasemiNejad, A. (2019). The Phillips curve in Iran: econometric versus artificial neural networks. Heliyon, 5, 16.

Johnes, G. (1999). Forecasting unemployment. Applied Economics Letters, 6, 605-607.

Katris, C. (2019). Prediction of unemployment rates with time series and machine learning techniques. Computational Economics, 55, 673-706.

Khan-Jaffur, Z. R., Sookia, N. U. H., Nunkoo Gonpot, P. and Seetanah, B. (2017). Out-ofsample forecasting of the Canadian unemployment rates using univariate models. Applied Economics Letters, 24, 1097-1101.

Kizilkaya, O. (2017). Türkiye'nin enflasyon ve işsizlik oranının yapay sinir ağları ve BoxJenkins yöntemiyle tahmini. Social Sciences Studies Journal, 3, 2197-2207.

Liliana, Napitupulu, T. A. (2012). Artificial neural network application in gross domestic product forecasting an Indonesia case. Journal of Theoretical and Applied Information Technology, 45, 410-415.

Nagao, S., Takeda, F. and Tanaka, R. (2019). Nowcasting of the US unemployment rate using google trends. Finance Research Letters, 30, 103-109.

Nakamura, E. (2005). Inflation forecasting using a neural network. Economics Letter, 86, 373-378.

Proietti, T. (2003). Forecasting the US unemployment rate. Computational Statistics and Data Analysis, 42, 451-476.

Popescu M. C., Olaru, O. and Mastorakis, N. (2009). Equilibrium dynamic systems integration proceedings of the 10th WSEAS, Int. Conf. on Automation \& Information, Prague, 424- 430.

Refenes, A. P. and White, H. (1998). Neural networks and financial economics, International Journal of Forecasting, 6 .

Sengul, G. and Tasci, M. (2020). Unemployment flows, participation, and the natural rate of unemployment: evidence from Turkey. Journal of Macroeconomics, 64(C), 1-14.

Sermpinis, G., Stasinakis, C., Theofilatos, K. and Karathanasopoulos, A. (2014). Inflation and unemployment forecasting with genetic support vector regression. Journal of Forecasting, 33, 471-487.

Soybilgen, B. and Yazgan, E. (2018). Nowcasting the new Turkish gdp. Economics Bulletin, 38, 1083-1089.

Teräsvirta, T., Van Dijk, D. and Medeiros, M. C. (2005). Linear models, smooth transition autoregressions, and neural networks for forecasting macroeconomic time Series: a reexamination. International Journal of Forecasting, 21, 755-774.

Thomas R. C. and Hall, A. S. (2017). Macroeconomic indicator forecasting with deep neural networks. Research Working Paper RWP, 17-11. 
Tkacz G. (2001). Neural network forecasting of Canadian gdp growth. International Journal of Forecasting, 17, 57-69.

Vicente, M. R., López-Menéndez, A. J. and Pérez, R. (2015). Forecasting unemployment with internet search data: does it help to improve predictions when job destruction is skyrocketing?. Technological Forecasting and Social Change, 92, 132-139.
Wozniak, M. (2020). Forecasting the unemployment rate over districts with the use of distinct methods. Studies in Nonlinear Dynamics \& Econometrics, De Gruyter, 24, 120.

Zhang, G., Patuwo, B. E. and Hu, M. Y. (1998). Forecasting with artificial neural networks: the state of the art. International Journal of Forecasting, 14, 35-62. 